\title{
Akut koronáriaszindróma miatt intervención átesett betegeink lipidcsökkentö kezelése és ajánlás a beavatkozás utáni ellenőrzésekre
}

\author{
Márk László1, Dani Győző², Ozsváth Lídia', Szabó-Györke István³, \\ Katona András ${ }^{1}$, Jambrik Zoltán ${ }^{1}$
}

\author{
'Békés Megyei Központi Kórház, Pándy Kálmán Tagkórház, Gyula \\ ²Városi Kórház, Orosháza \\ ${ }^{3}$ Békés Megyei Központi Kórház, Réthy Pál Tagkórház, Békéscsaba
}

Levelezési cím:

Dr. Márk László, e-mail: dr.mark.laszlo@gmail.com

\begin{abstract}
Bevezetés: A lipidcsökkentő terápia a kardiovaszkuláris prevenció egyik alapeleme és bár akut koronáriaszindrómán (ACS) átesett betegek esetén az irányelvekben előírt célértékek elérésének fokozott jelentősége van, jól ismert tény az is, hogy világszerte nem áll megfelelő szinten. A kezelés fontosságát jelzi, hogy az igen nagy kockázatú betegek korábbi 1,8 mmol/I LDL-koleszterin (LDL-C) célértékét a 2019es évi ajánlásban 1,4 mmol/l-re szállították le.

Célkitűzés: Annak vizsgálata, hogy hemodinamikai laboratóriummal rendelkező megyei kórházban az ACS miatt kezelt betegeket milyen lipidcsökkentő terápiával engedtük otthonukba és az invazív beavatkozás utáni első évben miként alakul az LDL-C-célértékek elérése. Módszer: A megyében működő három kórház adatbázisából retrospektív adatgyüjtés történt 2017-ben ACS miatt szívkatéteres intervención átesett betegek elbocsájtási terápiájáról, és az azt követő egy év lipidértékeiröl.

Eredmények: 2017-ben 513 beteget kezeltünk ACS miatt, 38,6\%-ban fordult elő ST-elevációs, 56,5\%-ban nem ST-elevációs infarktus, 4,9\%ban instabil angina. A betegek átlagos életkora 67,9 év volt. Elbocsátáskor a betegek 98,5\%-a kapott statinjavaslatot (20 mg rosuvastatin 1,5\%, $40 \mathrm{mg}$ rosuvastatin 94\%, $40 \mathrm{mg}$ rosuvastatin + ezetimib 3\%). Fél évnél 277 (54\%), egy évnél 269 esetben (52\%) találtunk lipideredményt a megye kórházainak adatbázisaiban. Az LDL-C-szint mediánja (mmol/l, [IQ-tartomány]) fél évnél 1,97 (1,26-2,77), egy évnél 2,04 (1,29-2,36), az 1,8 mmol/l célérték elérési gyakorisága fél évnél 52,7\%, egy évnél 48,0\%, az 1,4 mmol/l elérési arány 18,9 és 18,7\% volt. Következtetések: Az ACS miatt kezelt betegek kórházi elbocsátásakor ajánlott lipidcsökkentő kezelése megfelel az irányelvek előírásainak, de a célértékek elérése fél és egy évnél is lényegesen elmarad az elvárhatótól. Célszerủ lenne, ha a beteg ACS miatti kezelésekor adott intézményi zárójelentésen konkrét időpontokat tüntetnénk fel a későbbi ellenőrző vizsgálatokra és a beteg már ekkor beutalót kapna a 4-6 hét múlva ajánlott első kontrollja előtt elvégzendő lipidprofil vizsgálatra.
\end{abstract}

Kulcsszavak: akut koronáriaszindróma, rizikófaktorok, kardiovaszkuláris prevenció, statinok, irányelvek

The lipid lowering therapy of patients after intervention due to acute coronary syndrome and a recommendation for the further controls

Introduction: The lipid lowering therapy has become one of the basic elements of the cardiovascular prevention and also the attainment of the target levels recommended by the guidelines has an intensified importance in case of patients after acute coronary syndrome (ACS), but it is well known that all over the world this doesn't reach an acceptable level.

The relevance of this treatment is underlined by the fact that in the recommendations published in 2019 the LDL-cholesterol (LDL-C) goal level in case of very high risk patients has been lowered from 1.8 to $1.4 \mathrm{mmol} / \mathrm{l}$.

Aim: The evaluation of the lipid lowering therapy at the time of hospital discharge and the attainment of lipid levels in the first year after the intervention in a county hospital possessing hemodynamic possibilities.

Method: A retrospective data collection was performed in the database of the three hospitals of the county, regarding to therapy at discharge and the lipid levels followed over one year in case of patients undergone by coronary intervention due to ACS in 2017.

Results: We treated 513 patients with ACS in 2017, 38.6\% of them suffered from ST segment elevation-, $56.5 \%$ with non-ST segment elevation myocardial infarction and $4.9 \%$ from unstable angina. The mean age was 67.9 years. At the time of hospital discharge $98.5 \%$ of patients got recommendation for statin treatment $(1.5 \%$ for $20 \mathrm{mg}$ rosuvastatin, $94 \%$ for $40 \mathrm{mg}$ rosuvastatin and $3 \%$ for combination of $40 \mathrm{mg}$ rosuvastatin $+10 \mathrm{mg}$ ezetimibe). In the database of these hospitals, after 6 month of the discharge only 277 (54\%), after one year 269 (52\%) patients had lipid measurement results. The LDL-C average value (mmol/l, [IQ-range] was 1.97 (1.26-2.77) after half of a year, and $2.04(1.29-2.36)$ after one year, the attainment rate of $1.8 \mathrm{mmol} / /$ was $52.7 \%$ after 6 months of intervention, $48.0 \%$ after one year, the new target value $-1.4 \mathrm{mmol} / \mathrm{l}$ was reached in $18.9 \%$ and after one year in $18.7 \%$ of patients.

Conclusions: The lipid lowering therapy suggested at discharge to patients suffering from ACS correlates with recommendations of the guidelines, but the goal attainment at half- and at one year is below of expectations. It would be advisable to give exact dates for the forthcoming control exams in the final report of patients treated with ACS and to give them a referral for the first lipid profile lab analysis at 4-6 weeks.

Keywords: acute coronary syndrome, risk factors, cardiovascular prevention, statins, guidelines

A kézirat 2020. január 22-én érkezett a szerkesztőségbe, 2020. február 10-én került elfogadásra. 
Az ateroszklerózis, valamint egyes manifesztációi nagy terhet rónak napjaink egészségügyére mind a megelőzés mind a gyógykezelés tekintetében. Magyarországon jól kiépített és jól működő hálózat van az akut koronáriaszindróma (ACS) koronária-intervenciós kezelésére. Ennek eredményeként az ST-elevációs és nem ST-elevációs miokardiális infarktus (STEMI, NSTEMI) kórházi halálozás a nyugat-európai adatokhoz hasonló, de a későbbiek során (egy hónapnál és még inkább egy évnél) lényeges az elmaradásunk (1). Egyik oka az lehet, hogy az elbocsátáskor a betegek nem kapják meg az irányelvek által előírt terápiát. Munkánkban az ACS miatt perkután intervención $(\mathrm{PCl})$ átesett betegek szekunder prevenciós kezelésének egyik fontos részével, a lipidcsökkentő terápiával foglalkozunk. Ennek hangsúlyt ad az is, hogy 2019ben jelent meg az Európai Atherosclerosis Társaság (EAS) és az Európai Kardiológiai Társaság (ESC) új dyslipidaemia ajánlása, amely másfél évtized után módosította a kezelési célértékeket is $(2,3)$. Hogy áll a kardiológiai invazív laboratóriumunk vonzáskörében az ACS miatt PCl-n átesett betegek lipidcsökkentő kezelése? Milyen a régi 1,8 $\mathrm{mmol} / \mathrm{l}$ és milyen lenne az új, 1,4 mmol// LDL-koleszterin (LDL-C) célértékek elérési aránya? Korábban beszámoltunk a 2015-ben ACS-en átesett betegek körében hasonló módon végzett felmérésünk eredményeiről (4), és ezeket összehasonlítjuk a jelenlegi adatokkal.

\section{Betegek és módszer}

Vizsgálatunkat retrospektív adatgyüjtéssel végeztük a Békés Megyei Központi Kórház, Pándy Kálmán Tagkórház, Kardiológia Osztály Invazív Részlegén a 2017-ben ACS miatt $\mathrm{PCl}-\mathrm{n}$ átesett betegein. Felmértük, hogy a kórházi elbocsátáskor milyen lipidcsökkentő javaslattal engedtük otthonukba betegeinket és a megye 3 kórházában rendelkezésre álló adatbázisokban milyen lipidértékeket találtunk az esemény után fél és egy évvel. A vizsgálat végzéséhez a Békés Megyei Központi Kórház, Pándy Kálmán Tagkórháza Intézményi Kutatásetikai Bizottsága engedélyt adott.

A statisztikai elemzéseket SPSS 23.0 for Windows (SPSS, Chicago, IL, USA) programcsomag segítségé- vel végeztük. A kategorikus adatokat abszolút számokban és százalékokban, illetve a folyamatos változókat normáleloszlás esetén számtani közép és standard deviációval, nem normáleloszlás esetén medián és interkvartilis tartományokkal ábrázoltuk. A kategorikus adatokat Fisher-egzakt teszt alkalmazásával elemeztük; a folytonos változók összehasonlítása nem paraméteres Mann-Whitney U-teszttel történt. Minden feltüntetett p-érték kétoldalas és a $p<0,05$-ot tekintettük szignifikánsnak.

\section{Eredmények}

2017-ben a Nemzeti Szívinfarktus Regiszterbe (NSZR) bevitt adataink alapján 513 beteget vettünk fel ACS miatt, közel azonos arányban fordult elő ST-elevációs és nem ST-elevációs (STEMI, NSTEMI) infarktus. Az átlagos életkor ( $\pm S D$ ) 67,9 $\pm 12,2$ év volt, az NSTEMI-betegek átlagos életkora magasabbnak bizonyult $(p=0,003)$. A nők átlagos életkora is magasabbnak bizonyult mind STEMI, mind NSTEMI esetén, de NSTEMI esetén volt csak szignifikáns különbség $(p=0,002)$ (1. táblázat). A kórházban összesen 13 beteg (2,5\%) halt meg ( 5 férfi és 5 nő, akik STEMI, 1 férfi és 2 nő, akik NSTEMI miatt álltak kezelés alatt). A STEMI-esetek kórházi, 30 napos és 1 éves halálozása 5,4, 14,3 és $19,2 \%$ volt, NSTEMI esetében pedig $1,7,5,1$ és $15,3 \%$. Elbocsátáskor a betegek 98,5\%-a kapott statinjavaslatot, ez $20 \mathrm{mg}$ rosuvastatin 1,5\%-ban, $40 \mathrm{mg}$ rosuvastatin $94 \%$-ban és $40 \mathrm{mg}$ rosuvastatin + ezetimib 3\%-ban.

A kórházi adatbázisokban fél évnél 277 főnél (54\%), egy évnél 269 főnél (52\%) találtunk lipideredményt (ez 2015-16-ban a betegek 73\%-ánál volt meg). A lipideredmények, az 1,8 és 1,4 mmol// LDL-C elérésének aránya a 2. táblázatban látható. A LDL-C-szint átlaga (mmol/l, medián [IQ-tartomány]) fél évnél 1,97 (1,26$2,77)$, egy évnél 2,04 (1,29-2,36), az 1,8 mmol/l célérték elérési gyakorisága fél évnél $52,7 \%$, egy évnél $48,0 \%$ volt. Az új európai lipidcsökkentő irányelvekben javasolt 1,4 mmol/l célértéket 18,9, illetve 18,7\%-ban értük el. A férfiak és nők LDL-C átlaga és célérték elérési aránya közötti különbség (2. táblázat) nem volt szignifikáns.

1. TÁBLÁZAT. Akut koronáriaszindróma miatt osztályunkon 2017-ben kezelt betegeink jellemzői a Nemzeti Szívinfarktus Regiszter alapján

\begin{tabular}{|l|c|c|c|c|}
\hline & Összes & STEMI & NSTEMI & ISAP \\
\hline Betegszám (\%) & 513 & $198(38,6 \%)$ & $290(56,5 \%)$ & $25(4,9 \%)$ \\
\hline Életkor (év \pm SD) & $67,9 \pm 12,2$ & $66,1 \pm 11,6$ & $69,4 \pm 11.9$ & $64,4 \pm 15,9$ \\
\hline Férfiak (\%) & $306(59,6 \%)$ & $124(62,6 \%)$ & $164(56,6 \%)$ & $18(72 \%)$ \\
\hline Férfiak, életkor (év \pm SD) & $65,4 \pm 11,8$ & $64,8 \pm 11,9$ & $66,3 \pm 11,2$ & $61,5 \pm 19,2$ \\
\hline Nő (\%) & $207(40,4 \%)$ & $74(37,4 \%)$ & $126(43,4 \%)$ & $7(28 \%)$ \\
\hline Nök, életkor (év \pm SD) & $71,6 \pm 12,0$ & $68,4 \pm 12,4$ & $73,4 \pm 10.3$ & $72,0 \pm 2,82$ \\
\hline
\end{tabular}

ISAP = instabil angina pectoris; NSTEMI = nem ST-elevációs miokardiális infarktus; SD = standard deviáció; STEMI = ST-elevációs miokardiális infarktus 
2. TÁBLÁZAT. Az LDL-koleszterin és összkoleszterin-átlagértékek, valamint az 1,8 és 1,4 mmol/I LDL-koleszterin-célértékek elérési aránya fél és egy évvel a koronáriaesemény után

\begin{tabular}{|c|c|c|}
\hline & Fél év (277 fö) & Egy év (269 fö) \\
\hline LDL-koleszterin (mmol/l, medián [IQ-tartomány]) & $1,97(1,26-2,77)$ & $2,04(1,29-2,36)$ \\
\hline Összkoleszterin (mmol/l, medián [IQ-tartomány]) & $3,72(2,99-4,20)$ & $3,94(3,20-4,47)$ \\
\hline 1,8 mmol// LDL-koleszterin elérési aránya (\%) & 52,7 & 48,0 \\
\hline 1,4 mmol// LDL-koleszterin elérési aránya (\%) & 18,9 & 18,7 \\
\hline \multicolumn{3}{|l|}{ Férfiak } \\
\hline LDL-koleszterin (mmol/l, medián [IQ-tartomány]) & $1,96(1,13-2,20)$ & $2,24(1,20-3,36)$ \\
\hline Összkoleszterin (mmol/l, medián [IQ-tartomány]) & $3,67(2,81-4,15)$ & $4,09(3,20-4,74)$ \\
\hline 1,8 mmol// LDL-koleszterin elérési aránya (\%) & 53,9 & 42,1 \\
\hline 1,4 mmol// LDL-koleszterin elérési aránya (\%) & 15,4 & 10,5 \\
\hline \multicolumn{3}{|l|}{ Nők } \\
\hline LDL-koleszterin (mmol/I, medián [IQ-tartomány]) & $1,97(1,35-2,30)$ & $1,83(1,30-2,17)$ \\
\hline Összkoleszterin (mmol/l, medián [IQ-tartomány]) & $3,78(3,00-4,20)$ & $3,78(3,20-4,00)$ \\
\hline 1,8 mmol// LDL-koleszterin elérési aránya (\%) & 51,5 & 54,0 \\
\hline 1,4 mmol// LDL-koleszterin elérési aránya (\%) & 22,9 & 27,0 \\
\hline
\end{tabular}

\section{Megbeszélés}

A kezelési irányelvek lefektetik az egyes kórképek terápiájának alapelveit, de a napi gyakorlatban ezek tényleges megvalósulására nem mindig van reális lehetőség, vagy ami még gyakoribb, az ajánlásban előirt kezelés nem mindig ér el elfogadható szintet. Ez különösen igaz a lipidcsökkentő kezelésre, amelyben sokszorosan igazoltan és széles körben ismerten, a ténylegesen hozzáférhető gyógyszerekkel a betegeink érdekeit hosszabb távon jobban szolgáló eredményeket tudnánk elérni. Az ACS kiemelkedő jelentőségű ebből a szempontból is, mert ezen betegcsoport célértékekre kezelésével lehetne a legtöbb mortalitási és morbiditási hasznot elérni.
Az ESC/EAS (Európai Kardiológusok Tásasága/Európai Atherosclerosis Társaság) 2019-es lipidajánlása az utóbbi évek nagy klinikai vizsgálati eredményei alapján a korábbinál alacsonyabb LDL-C-célértékeket írt elő: igen nagy kockázatban az 1,8 helyett 1,4 mmol/l-t, illetve két éven belül ismétlődő éresemény esetén $1,0 \mathrm{mmol} / \mathrm{l}$ is megfontolható (2).

Az LDL-C-célértékek elérési aránya különböző időpontokban közölt más európai országokban végzett és magyar vizsgálatokban, valamint a jelen elemzésben látható az 1. ábrán $(5,6,7,8)$. Laikus kérdés lenne, hogy miért akarunk még alacsonyabb szinteket, amikor a magasabb régiek elérése is kívánni valót hagy maga után mindenütt Európában. Az ajánlás szerzőinek nem

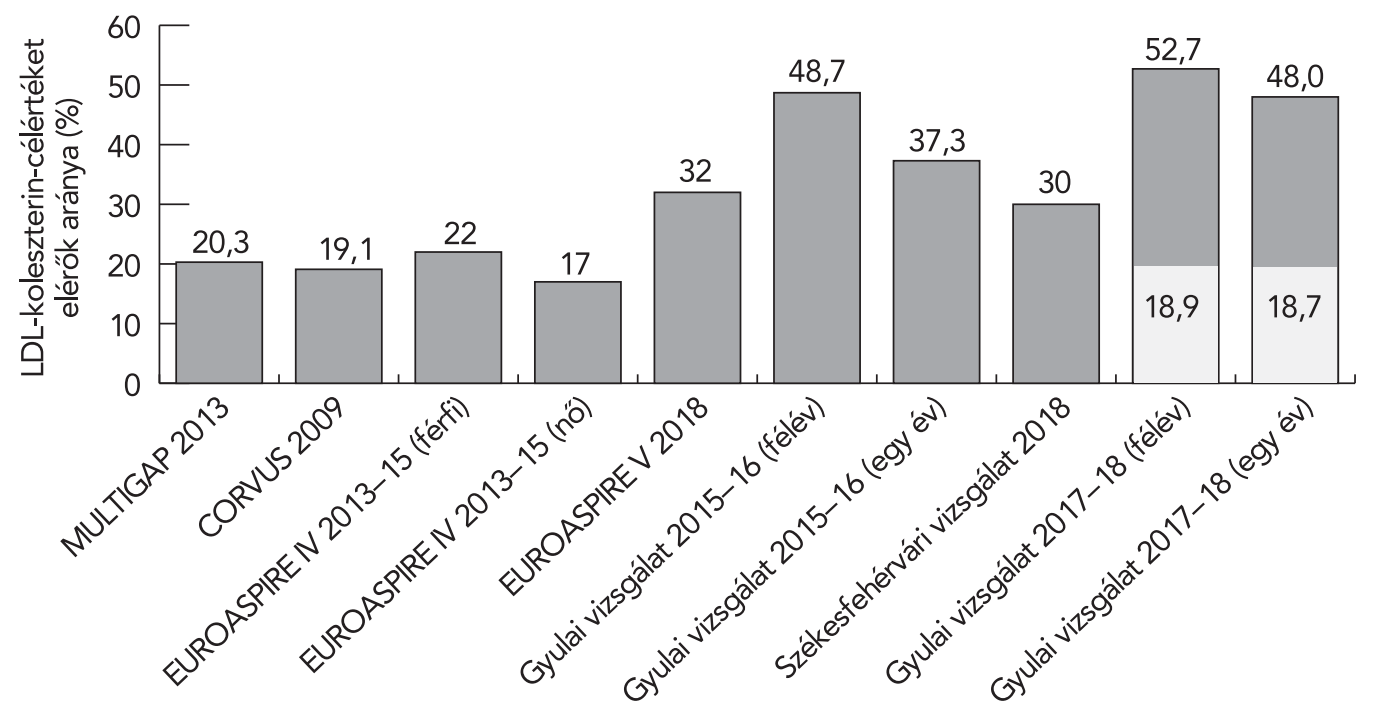

1. ÁBRA. Az 1,8 mmol// LDL-koleszterin-célértéket elérők aránya (\%) magyar és európai adatok alapján, 2018-as székesfehérvári, valamint a 2015-2016-os és a 2017-2018-as gyulai vizsgálatban (a két utolsó oszlopban jelöltük az 1,4 mmol/l elérésének arányát is) 
az a feladata, hogy a gyakorlathoz igazítsák az előírásokat, hanem az, hogy a Bizonyítékokon Alapuló Orvoslás elvei szerint elvégzett klinikai vizsgálati eredmények szintetizálásával megmutassák, miként tudnánk még jobb halálozási és megbetegedési eredményeket elérni.

Vizsgálatunkban fél és egy évvel az ACS után az LDLC-szint átlaga (mmol/l, medián [IQ-tartomány]) 1,97 $(1,26-2,77)$ és $2,04(1,29-2,36)$, az $1,8 \mathrm{mmol} / \mathrm{l}$ célérték-elérési gyakorisága $52,7 \%$ és $48,0 \%$. Ha a jelenleg érvényes európai irányelvek $1,4 \mathrm{mmol} / \mathrm{l}$ célértékét veszszük figyelembe, annak elérése fél évnél 18,9\%, egy évnél 18,7\%-ban valósul meg. Pedig klinikai vizsgálatok tömege igazolja, hogy alacsonyabb LDL-C kevesebb kardiovaszkuláris eseménnyel járna együtt.

A 2019-es év egyik legnagyobb horderejű vizsgálata az ISCHEMIA (International Study of Comparative Health Effectiveness with Medical and Invasive Approaches) volt, amelyben stabil koronáriabetegségben szenvedőkön vizsgálták az optimális gyógyszeres kezelés és az emellett alkalmazott PCl kardiovaszkuláris eseményekre kifejtett hatását. Tény, hogy ez a vizsgálat nem ACS utáni betegeken történt, de következtetései általános érvényűek arra vonatkozóan is, hogy a célértékek elérése mennyire fontos lenne a hosszú távú kezelésben (9).

Chamberlain és munkatársai 1854 nagy kardiovaszkuláris eseményen átesett beteg 5,9 éves követésével azt állapították meg, hogy szemben az 1,8 mmol// célértéket elérőkkel, azokban, akik LDL-C-szintje 2,6 mmol/l felett volt, szignifikánsan, 31\%-kal magasabb volt az újabb kardiovaszkuláris esemény vagy haláleset előfordulása (10). Az események fellépte oldaláról nézve mindegy, hogy a beteg az orvos oda nem figyelése vagy a saját rossz adherenciája miatt nem kapja az ideális kezelést. Rasmussen és munkatársai több mint 34 ezer beteg követésével a jó ( $80 \%$ vagy e feletti) és a rossz adherenciájú (40\% alatti) szívinfarktus utáni betegek halálozása között 25\%-os különbséget találtak (11). Hasonló következtetésre jutottak Rodriguez és munkatársai a közel 350 ezer amerikai érbeteg adherenciájának és halálozásának összefüggését tanulmányozó munkájukban: a jó és a rossz adherenciájú csoportok között 30\%-os halálozási különbséget írtak le (12).

\section{A vizsgálat következtetései és a szerzők ajánlása az ACS utáni betegek ellenőrző vizsgálataira}

Jelen vizsgálatunk alapján tevékenységünk legnagyobb hibájának a PCl-n átesett betegek gondozási hiányosságát tartjuk. 2015-16-ban a betegek 73\%-ánál találtunk lipideredményt, ami a 2017-18-as vizsgálatban $60 \%$ alá csökkent (fél évnél $54 \%$, egy évnél 52\%). A lipideredményeket a megye három kórházának adatbázisából nyertük, a megyében csak itt történnek akk- reditált laboratóriumi vizsgálatok. Azt gondoljuk, hogy a kórházi terápiás javaslatok meghatározóak a betegek további gyógykezelésében (betegeink túlnyomó többsége nagy intenzitású statinjavaslattal ment haza a $\mathrm{PCl}$ után). Ez egy fontos, de messze nem elégséges tényező az akut esemény után a betegek megfelelő hosszú távú gyógykezelésében és ellenőrzésében a recidívák megelőzésében. A szívinfarktust túlélt betegek gondozásának kérdése nincs egyértelműen megoldva, világosan megszervezve. Nincs szisztematikus visszahívási rendszer, esetleges a gondozást végző személy kérdése, lehet invazív kardiológus, szakrendelésen dolgozó kardiológus, családorvos, belgyógyász, lipidológus, magánorvos stb. Az esemény utáni kardiológiai rehabilitáció egyik nagy lehetőség a további terápia racionalizálására. Ennek során - az időintervallumokat figyelembe véve - megtörténhet az irányelvekben ajánlott 4-6 hetes lipidkontroll is és azt követően a szükséges gyógyszeres módosítás. Teljességgel érthető lehet az a törekvés, hogy a $\mathrm{PCl}$-t végző, egyébként túlterhelt invazív kardiológus szeretné első alkalommal látni a beteget, de ennek során az európai ajánlás szerint a lipidszintek ellenőrzésének is meg kellene történnie, és utána konkrét további ellenőrzési javaslatokkal kellene a beteget a következőkben a gondozást végző orvoshoz irányítani. Aki lehet szakorvos, lehet családorvos, de az aktuális irányelveket, beleértve a lipidcsökkentést is, alkalmaznia kell.

Ha figyelembe vesszük az 1,4 mmol/l igen nagy kockázatú célérték elérésének valószínűségét a különböző koleszterincsökkentési lehetőségekkel, az ezetimib alkalmazásának előtérbe kell kerülnie. Az elérési esély nagy intenzitású statinokkal is csak $50 \%$, ami ezetimibbel kombinálva 66\%-ra emelhető (ideális orvosi felírás és jó betegadherencia esetén várható ez az eredmény). A további javításhoz, a fennmaradó 34\%-ban a PCSK9-gátlók adása jön szóba $(3,13,14)$.

Jelenleg ezetimib emelt támogatású felírhatósága szakorvosi javaslathoz és megfelelő diagnózis alapján eü. ponthoz kötött, amin célszerü lenne változtatni. Ugyanakkor kimutatható, hogy az érvényes szabályozás adta lehetőségekkel sem élünk. Az NSZR adatai szerint 2019. december 27-ig 104912 beteg került regisztrálásra, akik közül 24,8\% korábban ST-elevációs szívinfarktuson és/vagy 22,0\% korábban PCl-n estek át. Ezen betegek számára (20-24\%-nak) már a kórházi távozáskor lehetett volna ezetimibet javasolni, de a bevitt adatok szerint ezt csak 2,6\% kapta meg.

A lipidcsökkentésre vonatkozó javaslatainkat a következőkben foglaljuk össze:

1. Az ACS miatt kezelt betegek elbocsátásakor ügyelni kell arra, hogy nagy hatékonyságú statint (lehetőleg $40 \mathrm{mg}$ rosuvastatint vagy $80 \mathrm{mg}$ atorvastatint) kapjanak. (Az irodalomban alkalmazott „maximálisan tolerált statin" kifejezés helyett szerencsésebb lenne a „biztonsággal adható maximális statinadag”, hiszen 60 alatti GFR-nél vagy manifeszt hypothyreosis ese- 
tén $40 \mathrm{mg}$ rosuvastatin csak óvatosan adható.) $\mathrm{Az}$ NSZR adatai alapján készült vizsgálatban ez az invazív centrumok és sok más intézmény esetén $90 \%$ feletti (természetesen ez is tovább javítható, de akad sok intézmény, ahol igen alacsony gyakoriságú az irányelvekben előírt statinadag alkalmazása) (15).

2. Elbocsátáskor a beteget lássuk el beutalóval a 4-6 hét múlva esedékes lipidvizsgálatra és az ellenőrző vizsgálat idejére kapjon pontos időpontot, valamint részesüljön életmódra és adherenciára vonatkozó tanácsadásban. A zárójelentésen a családorvost értesítsük a legközelebbi ellenőrzés tervezett pontos időpontjáról és a későbbre tervezett vizsgálatok hozzávetőleges idejéről (3-6-12 hónap).
3. Ha a beteg az ACS előtt nem szedett statint, és a 4-6 hét múlva esedékes kontroll során (ahova laborvizsgálati eredménnyel érkezik) elérte az 1,4 mmol// LDL-C-célértéket az életmódra és adherenciára vonatkozó ismételt tanácsadás mellett 3, majd 6 és 12 hónap múlva hívjuk ellenőrzésre. Ha nem érte el a célértéket, kapjon ezetimibet is. (A jelenlegi hazai szabályozási rendszer ezt csak 3 hónap után engedné eü. térítésköteles támogatással, de a Magyar Atherosclerosis Társaság és a Magyar Kardiológusok Társasága kérte a vonatkozó rendelet módosítását.). Ha ezetimib adását is elindítottuk, a beteg laborbeutalót kap és időpontot egy hónap múlva történő ellenőrzésre.

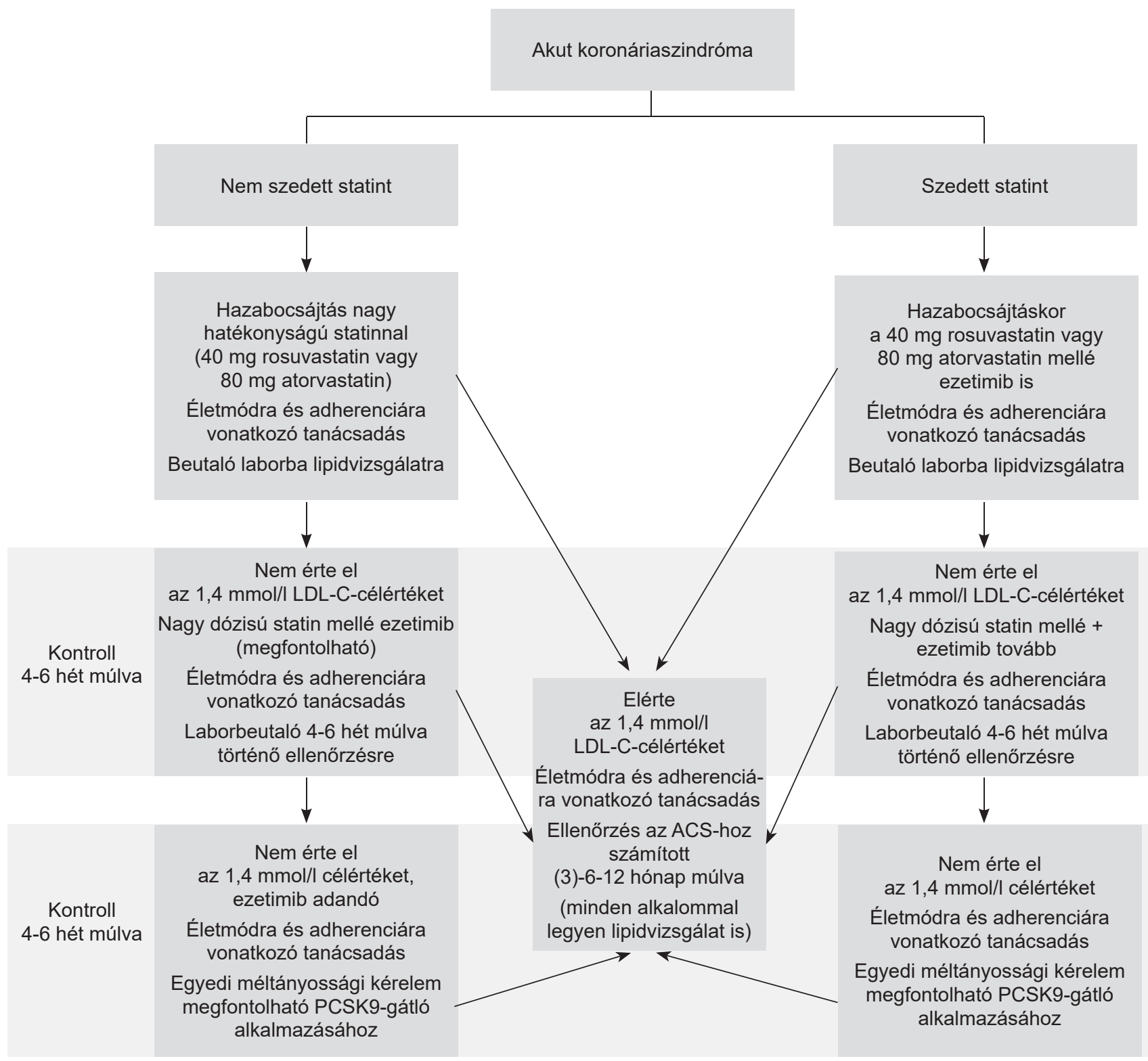

2. ÁBRA. Ajánlásunk az akut koronáriaszindrómán átesett betegek lipidcsökkentő ellenőrzésének megtervezéséhez 
4. Ha az ellenőrzéskor sincs célértéken az LDL-C, akkor egyedi méltányossági kérelem beadása megfontolható PCSK9-gátló alkalmazásának engedélyezéséhez.

5. Ha a beteg az ACS előtt statint szedett, akkor elengedésekor a $40 \mathrm{mg}$ rosuvastatin vagy $80 \mathrm{mg}$ atorvastatin mellé kapjon ezetimib javaslatot is. Ez a statint intenzív adagban szedők esetén a finanszírozási gyakorlat alapján adható, a nem intenzív formában szedők esetén az ajánlások szerint megfontolható kategóriában volna, ugyanakkor mérsékelt intenzitású statinnal is csupán $25 \%$ esély van az $1,4 \mathrm{mmol} / \mathrm{l}$ elérésére (14), kis intenzitású adag esetében sokkal kevesebb (nem kell a túlkezeléstől tartani, hisz nem gond, ha 1,4 mmol/l alá megyünk). A 4-6 hét múlva esedékes kardiológiai vizsgálatára kapjon pontos időpontot, oda friss labor- (lipid) eredménnyel jöjjön, amire el kellene látnunk a zárójelentés mellé adott beutalóval. Ha ezen maximális statin-ezetimib kezeléssel 3 hónappal az esemény után sincs célértéken, egyedi méltányossági kérelem megfontolható PCSK9-gátló alkalmazásának engedélyezéséhez (2. ábra).

6. Az életmódra és adherenciára vonatkozó tanácsadás fontos minden orvos-beteg-találkozáskor. Célszerű lenne már a $\mathrm{PCl}$ után közvetlenül tájékoztatnunk a betegeket a statinellenes közhangulatról és felvértezni a (sokszor orvos) statinszkeptikusok érvei és nemtelen a támadásai ellen. A wikipédia „statin” magyar szócikke is segíthet, mert független és hiteles forrásnak tekinthető (16). Mi a PCl-n átesett betegeinknek a beavatkozásról és a további preventív teendőkről szóló kis füzetet szoktunk adni.

Az ACS sürgősségi ellátásának magyarországi hálózata jól müködik, amit az is jelez, hogy ezen diagnózissal intézetbe kerülők halálozása a jó európai adatokhoz hasonló, de a későbbiek során „nyílik az olló”, nálunk lényegesen többen halnak meg (1). Ennek egyik lényeges oka lehet a betegek sokszor elégtelen, nem kellően strukturált gondozása (15). $\mathrm{Az}$ eredményeink alapján a $\mathrm{PCl}-\mathrm{n}$ átesettek egyik fontos eleme, a prevenció „mostohagyereke”, a lipidcsökkentő kezelés végzésére kívántunk konkrét javaslatot adni.

\section{Nyilatkozat}

A szerzők kijelentik, hogy a tanulmány megírásával kapcsolatban nem áll fenn velük szemben pénzügyi vagy egyéb lényeges összeütközés, összeférhetetlenségi ok, amelyek befolyásolhatják a tanulmány- ban bemutatott eredményeket, az abból levont következtetéseket vagy azok értelmezését.

\section{Irodalom}

1. Jánosi A. Adatok a szívinfarktus miatt kezelt betegek ellátásának helyzetéről. Nemzeti Szívinfarktus Regiszter 2014-2018. Card Hung 2019; 49: 249-254. DOI: 10.26430/CHUNGARICA.2019.49.4.249

2. Mach F, Baigent C, Catapano AL, et al; ESC Scientific Document Group. 2019 ESC/EAS Guidelines for the management of dyslipidaemias: lipid modification to reduce cardiovascular risk. Eur Heart J 2020; 41: 111-188. doi: 10.1093/eurheartj/ehz455

3. Bajnok L. Az Európai Ateroszklerózis Társaság (EAS) és az Európai Kardiológiai Társaság (ESC) dyslipidaemia ajánlása. Fókuszban az igen nagy kockázatúak. Metabolizmus 2019; 17: 262-265.

4. Márk L. Nagy M, Dani Gy, et al. Akut coronariaszindróma miatt 2015-ben kezelt betegeink lipidcsökkentő terápiája Orv Hetil 2018; 159: 478-484. DOI: 10.1556/650.2018.31022

5. A VII. Magyar Kardiovaszkuláris Konszenzus Konferencia ajánlásai. Metabolizmus 2018; 16: 1-66.

6. Márk L. Hány cardiovascularis eseményt előzhetünk meg a prevenciós elvek szerint vezetett lipidcsökkentő kezeléssel? LAM 2019; 29: 289-294. DOI: https://doi.org/10.33616/lam.29.029

7. De Backer G, Jankowski P, Kotseva K, et al; EUROASPIRE V collaborators; Management of dyslipidaemia in patients with coronary heart disease: Results from the ESC-EORP EUROASPIRE V survey in 27 countries. Atherosclerosis 2019; 285: 135-146. DOI: 10.1016/j. atherosclerosis.2019.03.014

8. Noori E, Bácsi A, József I, et al. A lipidcsökkentő kezelés gyakorlata és a lipidparaméterek alakulása akut koronáriaszindróma után. Metabolizmus 2019; 17: 77-81.

9. Hochman J, Spertus J. International Study of Comparative Health Effectiveness With Medical and Invasive Approaches - ISCHEMIA. AHA 2019 Scientific Sessions Presented 16 NOV 2019.

10. Chamberlain AM, Cohen SS, Weston SA, el at. Relation of cardiovascular events and deaths to Low-Density Lipoprotein cholesterol level among statin-treated patients with atherosclerotic cardiovascular disease. Am J Cardiol 2019; 123: 1739-1744. DOI: 10.1016/j.amjcard.2019.02.043

11. Rasmussen JN, Chong A, Alter DA. Relationship between adherence to evidence-based pharmacotherapy and long-term mortality after acute myocardial infarction. JAMA 2007; 297: 177-186. DOI: 10.1001/jama.297.2.177

12. Rodriguez F, Maron DJ, Knowles JW, et al. Association of statin adherence with mortality in patients with atherosclerotic cardiovascular disease. JAMA Cardiol 2019; 4: 206-213. doi: 10.1001/jamacardio.2018.4936

13. Cannon CP, Khan I, Klimchak A, et al. Simulation of lipid-lowering therapy intensification in a population with atherosclerotic cardiovascular disease. JAMA Cardiol 2017; 2: 959-966. doi: 10.1001/ jamacardio.2017.2289

14. Márk L, Reiber I, Bajnok L. Az ESC/EAS 2019. évi lipid ajánlása, az LDL-koleszterin célérték elérésének lehetőségei szivinfarktuson átesett igen nagy kockázatú betegekben. Card Hung 2020; 50: Közlés alatt.

15. Márk L, Jánosi A, Ferenci T, Andréka P. Szívinfarktust túlélt betegek lipidcsökkentő kezelése Magyarországon a Nemzeti Szívinfarktus Regiszter adatai alapján. Card Hung 2019; 49: 241-248. DOI: 10.26430/CHUNGARICA.2019.49.4.241

16. https://hu.wikipedia.org/wiki/Sztatin 